\title{
Interest rate, liquidity and stock market performance in Ghana
}

\author{
Micheal Kofi Boachie $^{1 *}$, Isaac Osei Mensah ${ }^{2}$, Albert Opoku Frimpong ${ }^{3}$, Martin Ruzima ${ }^{1}$ \\ ${ }^{1}$ Department of Economics, Annamalai University, Annamalai Nagar, Tamil Nadu, India \\ ${ }^{2}$ Bank of Ghana, Accra, Ghana \\ ${ }^{3}$ Department of Economics, Kwame Nkrumah University of Science and Technology, Kumasi, Ghana \\ *Corresponding author E-mail: mkboachie@gmail.com
}

\begin{abstract}
In this study, we examined the effect of interest rate and liquidity growth on stock market performance in Ghana using monthly data from the Ghana Stock Exchange and Bank of Ghana for the period 2010:12 to 2013:11. After employing robust linear regression (MEstimation), there is a compelling evidence that performance of the Ghanaian stock market is highly influenced by liquidity growth, exchange rate and inflation; and that interest rate effect is insignificant though positive on the stock market index for the period under study.
\end{abstract}

Keywords: Liquidity; Stock Market Index; Exchange Rate; Inflation; Interest Rate; Ghana

\section{Introduction}

Saving and investment (capital formation) remain an integral part of determining long run economic growth and development. The role of financial markets in the economic development process cannot be over emphasised. Financial markets facilitate the flow of funds from savers to investors through their intermediary role. In effect, they lower the cost of capital to investors through the provision of institutional mechanisms for mobilising domestic savings and efficiently channelling them into productive investments. Consequently, the overall development of the economy is a function of how well the financial sector performs; and studies like Mckinnon (1973), Shaw (1973), Singh (1997) inter alia have proved that a well developed financial system is sine qua non for economic growth since the sector accelerates savings mobilisation and investment.

Traditionally, financial intermediation is usually done through banks, and non-bank financial institutions. However, with time, financial intermediation shifts from bank-based system towards capital market (often dominated by stock markets) based system (Khan, 2004). The development of capital markets that deal with securities such as stocks and long-term bonds help facilitate equity financing for firms and other investors, and government towards production. Generally, resource mobilisation on the capital market is done for a long period.

The stock market has been the most popular and important source for companies (private and public) to raise funds even though other fund raising avenues exist. By this, companies raise additional capital for expansion by selling shares of ownership of the company in a public market. This appreciably raises the intensity of domestic savings and contributes to a more efficient allocation of such savings among competing uses (Engberg, 1975). Stock markets, therefore, have higher strength to break the vicious cycle of low rate of savings and investment that has bedevilled developing countries.

Typically, stock markets dominate banks because of their high liquidity, i.e. ease to convert illiquid assets into cash, effectiveness to exchange information among shareholders, business community, and prospective investors, and high degree of facilitating transactions, which contribute immensely to economic growth (Khan, 2004). In view of this, prices of stocks and other financial assets are important part of the dynamics of economic activities in the country. Recently, economies with strong and efficient stock markets are considered vibrant and profitable for investment. Stock markets, more often than not, serve as an indicator of business cycles and also play a crucial role in financial development (Khan, 2004; Worthington and Higgs, 2006; Aduda et al., 2012). However, most developing countries, including Ghana, have not fully utilised the opportunities that capital markets provide.

Over the last three decades, Ghana's financial sector has witnessed significant developments following the adoption of the Structural and Economic Recovery Programmes in the early 1980s. Among the developments were the introduction of flexible exchange rate regime, deregulation of interest rates controls and credit rationing. Further, to encourage domestic resource mobilisation and private sector participation in economic development, the Ghana Stock Exchange (GSE) was established in the late 1980s. Its full operations began in 1990 with the main aim of enabling companies raise funding for productive ventures.

Indeed, the ability of capital markets, and in particular stock markets, to play their ascribed role depends on the presence of market efficiency that has serious implications for capital allocation within an economy. Investing in the capital market would be easier if there is a particular bond between a specific assets return and the general economy. However, for many assets, especially common stocks, the linkages between an asset's price and the general economy are multifaceted. Unlike matured stock markets in advanced economies, the stock markets in developing and emerging economies are mostly volatile and inefficient due to inflation, liquidity, volatility in exchange and interest rates, and, sometimes, political pressures (Engel and Rangel, 2005). This makes such capital markets, sometimes, unattractive.

While the banking sector still dominates Ghana's financial sector, the GSE has performed creditably in the past years though it experienced some level of slowdowns, for instance as occurred in 1995. Listed companies have grown from 11 in 1990 to 37 in early 2014, and the trend is likely to continue. The GSE emerged the 
best index performing emerging stock market after moving from its sixth position in 1993. Again, a research conducted by Databank Ghana Limited on Africa's biggest 14 stock markets found GSE as the best performing stock market in Africa.

It is argued that the performance of financial and capital markets is influenced by the general performance of the economy through indicators like inflation and interest rates (see Ross, 1986). Evidently, different scholars have shown that the performance of stock markets in advanced countries is connected to the general performance of the economy (see for instance: Mukhopadhyay and Sarkar, 2003; Gan et al., 2006; Robert, 2008). The aim has usually been to discover the direction of relationship between macroeconomic indicators and stock market performance in the developed world. In fact, economic indicators in Ghana have been fluctuating, particularly through the 1990 s to 2000 s. Inflation, exchange rates, interest rates, and liquidity have witnessed considerable changes.

In view of this, there is the need to investigate whether the performance of the Ghana's stock market has been influenced by interest rate and liquidity growth taking into account their directions and magnitudes of influence. This is important because the estimation of future trends of macroeconomic indicators like interest rates and liquidity growth can be useful in seeing the future direction of Ghana's stock market. Thus, the present paper attempts to investigate the effect macroeconomic indicators on stock market performance in Ghana by focusing on interest rate and liquidity growth.

\section{Related literature}

There exists an expansive literature on the relationship between returns on assets and a range of macroeconomic factors. Undeniably, many researchers have tried to determine the link between selected indicators (internal and external, market and non-market, economic and noneconomic factors) and stock prices or stock market performance. Usually, the conclusions of these studies diverge depending on the scope of the study, the assets and sometimes the factors examined. In this section, we briefly review literature on stock market performance and the effect of macroeconomic indicators.

\subsection{Stock market performance: theoretical background}

It is commonly acknowledged that multiple risk factors elucidate the returns on assets and investments, and the Arbitrage Pricing Theory due to Ross (1976) does not contravene this belief. The theory asserts that the asset price (or its return) is influenced by both the market and non-market factors such as foreign exchange rate, inflation and unemployment rates inter alia. Indeed, the Arbitrage Pricing Theory (APT) has been one of the main channels of linking macroeconomic indicators and stock market returns (Ross, 1976). Thus, the APT assumes that the return on asset or investment is a function of various macroeconomic factors or market indices, where sensitivity to changes in each factor is proxied by a factor-specific beta coefficient. Thus, the APT is characterized by modelling a short run relationship between macroeconomic indicators and stock performance. One other theory is the Present Value Model (PVM) which makes use of the principle of discounted cash flow where stock prices are related to the future expected cash flows and the future discount rate of the cash flows. Thus, the PVM can be used to focus on the long run relationship between the stock market and macroeconomic variables.

\subsection{Empirical studies}

Empirically, in their quest to test the validity and applicability of APT, Chen et al (1986) investigated a set of macroeconomic indicators as systematic influence on stock market returns by modelling equity return as a function of macroeconomic variables and non-equity assets returns for the US economy. The macroeconomic variables included industrial production, inflation (both expected and unexpected), yield spread between the long and short term government bonds. The findings were that macroeconomic variables significantly explained the stock market returns. An analogous study in US by Ratanapakorn and Sharma (2007) found that the stock price index related positively to industrial production, inflation, money supply, short term interest rate and exchange rate, and negatively related to long term interest rate after applying Johansen's co-integration technique and vector error correction model (VECM) to US stock index and macroeconomic variables.

The analysis of the Japanese stock market by Hamao (1988) within the multi-factor APT framework revealed that stock returns are significantly influenced by the changes in inflation (expected), unexpected changes in both the risk premium and the gradient of the term structure of interest rates. Similarly, Mukherjee and Naka (1995) applied the vector error correction model (VECM) to stock market performance and macroeconomic indicators (inflation, money supply, exchange rate, industrial production index, and call money rate) in Japan. Long-run equilibrium relationship was established between stock market performance and the selected economic indicators.

In Singapore, the nexus between stock returns and macroeconomic variables such as narrow money supply, broad money supply, exchange rates and foreign exchange reserves using monthly data from October 1984 to April 1993 was examined by Mookerjee and Yu (1997). There was co-integrating relationship between stock prices and the selected macroeconomic variables except exchange rates. Also, Maysami and Koh (2000) investigated the relationships between the Singapore stock index and selected macroeconomic variables over a seven-year period and observed that there exists a positive association between stock returns (or performance) and changes in money supply but negative association between stock returns with changes in price levels, short- and long-term interest rates and exchange rates. Maysami et al (2004) also examined relationship between macroeconomic variables and stock market indices in Singapore and found that macroeconomic variables affect stock markets with inflation being positive on stock prices.

Wongbangpo and Sharma (2002) also studied the relationship between stock markets and fundamental macroeconomic factors in the five South East Asian economies (Indonesia, Malaysia, Philippines, Singapore, and Thailand) using monthly data on Gross National Product (GNP), consumer price index, money supply, interest rate, and exchange rate. They found that high inflation in Indonesia and Philippines influences the long-run negative relationship between stock prices and the money supply, whilst the money growth in Malaysia, Singapore, and Thailand induces the positive effect for their stock markets. The exchange rate variable was positively related to stock prices in Indonesia, Malaysia, and Philippines but negatively related in Singapore and Thailand. Chancharat et al (2007) found that money supply, thus liquidity growth has no impact on stock returns. In the works of Pearce and Roley (1983) and, Serletis (1993) monetary variables (e.g. money supply/liquidity) and stock returns were found to have no long run relationship.

Moreover, in Nigeria, Ologunde et al (2006) found that the prevailing interest rate exerts positive influence on stock market capitalization. Similarly, Oyinlola et al (2012) examined the dynamics between stock prices and exchange rate using the Johansen and Gregory-Hansen co-integration analyses and found no long run relationship between stock prices and exchange rate in Nigeria. In the work of Osamwonyi and Evbayiro-Osagie (2012), exchange rate was found to be positively related to stock market in the short run but negative in the long-run.

In Ghana, Osei (2006) investigated the relationships between the Ghana stock market and macroeconomic variables and established a cointegration between the macroeconomic variables and Ghana's stock market. Also, Anokye and Tweneboah (2008) examined the role of macroeconomic variables on stock returns 
using quarterly data on the Databank stock index (proxy for Ghana's Stock market) and inward foreign direct investment, treasury bill rate (as a measure of interest rate), consumer price index (as a measure of inflation) and exchange rate. They found cointegration relationship between selected macroeconomic indicators and stock market movement, and that interest rate and foreign direct investment (FDI) were the key determinants of the share price movements in Ghana after estimating impulse Response Function (IRF) and Forecast Error Variance decomposition (FEVD).

Further, Kyereboah and Agyire (2008) investigated how macroeconomic indicators affect the performance of Ghana stock market by means of quarterly time series data. They observed that lending rate from deposit money banks exerts an adverse effect on stock market performance and, in particular, serve as major impediment to business growth in Ghana. The rate of inflation related negatively to stock market performance.

Again, Adjasi et al. (2008) studied the relationship between stock markets and foreign exchange markets using EGARCH model to establishing the relationship between exchange rate volatility and stock market volatility. They find negative relationship between exchange rate volatility and stock market returns. Applying ordinary least squares (OLS) estimation in the context of BoxJenkins time series methodology, Kuwornu and Owusu-Nantwi (2011) revealed a significant relationship between stock market returns and consumer price index, i.e. inflation. On the other hand, crude oil prices, exchange rate and interest rate did not have any significant effect on stock returns. Very recent results from Johansen co-integration and VECM framework suggest that existence of a long-run relationship between stock prices and macroeconomic variables including exchange rate in Ghana. The relationship was negative for exchange rate and inflation whilst interest rate and oil prices were positive (see Osei-Fosu and Osei-Fosu, 2013).

Following from the literature, the impact of macroeconomic indicators on stock market performance are mixed, particularly interest rate and liquidity. Different methodologies have been applied to test the relationships between macroeconomic variables and stock market performance in various economies under different periods. While there is no standardisation of set of macroeconomic variables adopted by various studies, indicators like inflation rate, exchange rate, interest rate, and money supply (as a measure of liquidity) have commonly been used in explaining the stock market movement. While several studies exist on Ghana, no study utilised the APT and PVM theories which are the basic theories explaining stock market performance.

\section{Methodology}

\subsection{Data and variables}

For the purposes of this study, monthly time series data were sourced from the Ghana Stock Exchange (GSE), and Bank of Ghana (BoG). The macroeconomic indicators used as independent variables were interest rate $(\mathrm{R})$ to capture the cost of capital. The 91 day Treasury Bill Rate is used as proxy for interest rate while broad money supply (M2+) served as a measure of liquidity growth (LQT) in the economy. Again, the inflation Rate (INFL) is the consumer price index and is used to proxy the level of macroeconomic stability in the economy.

Further, Exchange Rate (EXR) per US dollar is used to capture the effects of currency depreciation or appreciation in relation to the subject matter. The exchange rate is the price of a unit of one currency in relation to other currencies. To be more specific, it is the units of domestic currency, say Ghanaian cedis, that are required to buy a unit of foreign currency, say US dollar, so that a fall in the exchange rate would depict an appreciation of the domestic currency. Thus, how much cedis a person requires to buy one US dollar is the exchange rate.
Conversely, the exchange rate can also be quoted in terms of the units of foreign currency required to get a unit of domestic currency so that a fall in the exchange rate would imply a depreciation of the domestic currency (see Mishkin, 2004 for detailed discussion on exchange rates). For the purposes of this study, the former definition of exchange rate is adopted. The performance and profitability of industries and companies that are major importers of raw materials are severely affected when the local currency depreciates and has the potential to affect the stock market as well. Finally, the performance of the stock market was measured by the GSE-Composite Index (GSECID) since it is the latest performance index. The study used monthly data covering the period between 2010:12 and 2013:11.

\subsection{Model specification}

Guided by the extant literature reviewed on stock market performance, the empirical specification to capture the effect of interest rates and liquidity growth while controlling for exchange rate and inflation on stock market is rooted in the Arbitrage Pricing Theory (APT). Thus, we put forward an empirical model as follows:

$\operatorname{GSECID}=\varphi+\beta_{1} \mathrm{R}+\beta_{2} \mathrm{LQT}+\beta_{3}$ INFL $+\beta_{4}$ EXR $+\varepsilon_{\mathrm{i}}$

In empirical estimation, all the variables in equation (1) were transformed into their logarithmic form to achieve uniformity in the units of the variables while correcting any skewness in the data. The log transformation also provides elasticities for easy interpretation of the results. The empirical log-linear model is presented as follows:

$$
\begin{aligned}
& \text { LNGSECID }=\varphi+\beta_{1} \text { LNR }+\beta_{2} \text { LNLQT }+\beta_{3} \text { LNINFL }+ \\
& \beta_{4} \text { LNEXR }+\varepsilon_{i}
\end{aligned}
$$

The definitions of the variables are as explained earlier. The $\beta_{\mathrm{s}}$ are the elasticity coefficients of the various independent variables, $\varphi$ captures the intercept term while $\varepsilon_{\mathrm{i}}$ is the disturbance term in the equations and its assumed to be normally distributed with zero mean and constant variance

As specified earlier, our aim for the present study was to determine whether interest rate and liquidity growth have any significant effect on the performance of stock markets, and if any the directions of relationship. By this, we make use of robust linear regression also known as M-Estimation to ascertain the direction of relationship between stock markets performance and macroeconomic indicators in Ghana focusing on interest rate. The M-Estimation technique was chosen because of the non-normality of the distribution of the series under study while avoiding the problems of heteroskedasticity, and serial correlation (a possibility we anticipate due to the distribution of the variables). Statistical significance is achieved by p-value of 0.05 or less within $95 \%$ confidence interval. STATA version 11 econometric package was used in all statistical analysis.

\subsection{Robust regression (m-estimation): an overview}

Robust linear regression is designed to evade some limitations of traditional parametric methods. Ordinary least squares (OLS) plays a significant role in the estimation field since they have favourable properties if their underlying assumptions (absence of heteroskedasticity, serial correlation and multicolinearity) are met (see for instance Gujarati, 2004). However, the assumptions of the classical linear regression are not usually met in practice hence the need to seek methods which could remedy this problem. In situations where the error distribution is not normal, the linear least squares can behave badly. We used the robust estimation method due to Huber (1964) to overcome the shortfalls of the OLS Consider a linear model:

$y_{i}=X_{i}^{\prime} \beta+\varepsilon_{i}$ 
The fitted model for (1) is given as:

$\mathrm{y}_{\mathrm{i}}=\mathrm{X}_{\mathrm{i}}^{\prime} \mathrm{b}+\mathrm{e}_{\mathrm{i}}$

Then Huber (1964) M - estimator minimises the function

$\sum_{i=1}^{n} \rho\left(e_{i}\right)=\sum_{i=1}^{n} \rho\left(y_{i}-x_{i}^{\prime} b\right)$

Where $\rho$ gives the contribution of each residual to the objective function in (5) and that $\rho$ should be positive, symmetric, and non-decreasing function of $\mathrm{x}$. Let $\psi=\rho$ ' be the derivative of $\rho$. Differentiating the objective function with respect to the coefficients, $\mathrm{b}$, and setting the partial derivatives to 0 , produces a system of $\mathrm{k}+1$ estimating equations for the coefficients:

$\sum_{i=1}^{n} \psi\left(y_{i}-x_{i}^{\prime} b\right) x_{i}^{\prime}=0$

Define the weight function $\omega(\mathrm{e})=\psi(\mathrm{e}) / \mathrm{e}$, and let $\omega_{\mathrm{i}}=\omega\left(\mathrm{e}_{\mathrm{i}}\right)$ Then the estimating equation may be written as:

$\sum_{i=1}^{n} \omega_{i}\left(y_{i}-x_{i}^{\prime} b\right) x_{i}^{\prime}=0$

Solving the estimating equation is a weighted least-squares problem, minimising $\sum \omega_{i}^{2} e_{i}^{2}$. Note, however, that the weights depend upon the residuals, the residuals depend upon the estimated coefficients, and the estimated coefficients depend upon the weights. An iterative solution will produce results devoid of heteroskedasticity, serial correlation and multicolinearity. Thus, the asymptotic covariance matrix of $b$ is therefore given as:

$v(b)=\frac{E\left(\psi^{2}\right)}{\left[E\left(\psi^{\prime}\right)\right]^{2}}\left(\chi^{\prime} \chi\right)^{-1}$

In doing this, the robust regression (M-Estimation) becomes robust to outliers in the response variables with high level of efficiency in the results. It is for this reason that we employ M-Estimation in the present study.

\section{Empirical results and discussion}

\subsection{Descriptive statistics}

The descriptive statistics for the 5-variables under study, namely, GSE composite index is proxied for stock market performance, interest rate, liquidity, and monthly average exchange rate (EXR) are presented in Table 1 . The symmetric nature in the distribution of the variables is indicated by the value of skewness and kurtosis. In general, if the value of skewness and kurtosis are 0 and 3 respectively, the observed distribution is said to be normal.

Further, if the skewness coefficient is in excess of unity it is considered extreme. Usually, the kurtosis of the normal distribution is 3 . If the kurtosis exceeds 3 , then the distribution is peaked (leptokurtic) relative to the normal, and if it is less than 3 it signifies flat (platykurtic) distribution relative to the normal. In addition, a significant (5\% level) coefficient of Jarque-Bera statistics suggests that the frequency distributions of considered series are not normal.

Table 1: Descriptive Statistics

\begin{tabular}{llllll}
\multicolumn{7}{c}{ Table 1: Descriptive Statistics } \\
& GSECID & $\begin{array}{l}\text { R } \\
(\text { TBR })\end{array}$ & $\begin{array}{l}\text { LQT } \\
(\mathrm{M} 2+)\end{array}$ & INFL & EXR \\
\hline Mean & 1304.34 & 16.94 & 19294.18 & 9.56 & 1.74 \\
Median & 1108.33 & 18.08 & 19868.38 & 9.12 & 1.84 \\
Maximum & 2123.75 & 23.09 & 25843.80 & 13.20 & 2.08 \\
Minimum & 969.03 & 9.13 & 13644.88 & 6.34 & 1.47 \\
Std. Dev. & 390.12 & 5.80 & 3541.94 & 1.44 & 0.20 \\
Skewness & 1.08 & -0.09 & -0.15 & 0.89 & -0.12 \\
Kurtosis & 2.46 & 1.17 & 1.78 & 3.72 & 1.42 \\
Jarque- & 7.38 & 5.07 & 2.37 & 5.54 & 3.85 \\
Bera & & 0.08 & 0.31 & 0.06 & 0.15 \\
Probability & 0.03 & 36 & 36 & 36 & 36 \\
Obs & 36 & & & & \\
\hline
\end{tabular}

Source: Authors' Computation based on GSE and BoG raw data

It can be observed from Table 1 that the frequency distributions of the underlying variables are normal except the index for stock market performance (GSECID). There was some level of volatility in all the series as indicated by the standard deviation. It is obvious that except inflation, all the variables were "platykurtically" distributed as indicated by the kurtosis. Our choice of robust estimation is appropriate due to the nature of the distribution of the variables under study.

The GSE composite index has shown an upward trend though there has been some level of volatility over the period under study. The index has averaged at 1304.34 between 2010:12 and 2013:11 signifying better performance. Within this same period, the price of dollar (exchange rate) in cedi terms has been rising at a faster rate. Liquidity growth also saw an upward trend, especially in the year 2012 which was an election year. Again, inflation that had been stable began to rise after 2012 while interest rate ( $T$ ' Bill Rate) rose sharply from $9.13 \%$ in $2011: 10$ to $23.09 \%$ in $2012: 10$. This could be due to government's efforts to raise more funds to complete ongoing projects while embarking on new ones, given that 2012 was an election year. Obviously, one might think of this as a way of crowding out available funds from the private sector.

\subsection{Empirical results and discussion}

In order to find the impact of interest rate and liquidity on the performance of Ghana's stock market, robust linear regression was employed. Table 2 shows the regression results on the impact of selected macroeconomic indicators and stock market performance with particular variables of interest.

Table 2: Interest Rate, Liquidity and Stock Market Performance

\begin{tabular}{lllll}
\hline & Coeff. & t-ratio & $95 \%$ CI & \\
\hline Interest rate & 0.0732 & 1.43 & -0.0312 & 0.1776 \\
Liquidity growth & 1.8823 & $3.73 * * *$ & 0.8527 & 2.9120 \\
Inflation rate & 0.6472 & $9.91 * * *$ & 0.5138 & 0.7805 \\
Exchange Rate & -0.2150 & $-3.26 * * *$ & -0.3496 & -0.0804 \\
Intercept & -3.0739 & $-2.52 * *$ & -5.5681 & -0.5797 \\
\hline$*(* *) * * *$ denote significance at $10 \%, 5 \%$ and $1 \%$ level respectively
\end{tabular}

The parameter estimates are robust and very satisfactory as well. The overall model was good since the p-value for the F-statistic was zero and the coefficients fell within the $95 \%$ confidence interval. The coefficient of determination, $\mathrm{R}^{2}$, was 0.727 . The implication is that about $73 \%$ of the movements in Ghana's stock market is explained by the independent variables presented in equation (2).

As seen from Table 2, only interest rate was not statistically significant in influencing the performance of stock market in Ghana; and its elasticity was the lowest though positive. A similar sign was found by Ologunde et al (2006); Anokye and Tweneboah (2008) as well as Osei-Fosu and Osei-Fosu (2013). Thus, a percentage point increase in the interest rate causes only $0.073 \%$ increase in the GSE composite index (if it were statistically significant). The low interest rate elasticity and its insignificant effect on stock market performance support Kuwornu and Owusu-Nantwi (2011) findings that interest rate is ineffective on stock market. This finding however deviates from the results of Anokye and Tweneboah (2008) which suggest that interest rate is very influential in Ghana's stock market movements. Indeed, the risky nature of stocks makes it more attractive for investors to protect their funds by investing in interest bearing assets. Thus, many investors shy away from stock markets just to safeguard their hard-earned money because of the inefficiencies and high level of volatility associated with many stock markets in developing countries, a possible reason for the present result. It is intuitive to note that the insignificance of interest rate ( $T$ ' Bill Rate) is suggestive of the fact that government borrowing did not crowd out funds from the private sector.

Also, increase in money supply leads to increased liquidity that ultimately results in upward movement of nominal stock prices 
since people try to dispose excess money balances by purchasing assets including stocks. It must, however, be noted that monetary growth, except accompanied by output growth, leads to inflationary spiral in the economy, and as investors diversify their portfolio holdings away from financial assets to real assets it might drive stock prices downwards. This measure is often adopted, by investors, to hedge against the erosive effect of inflation on financial assets. However, in periods of recession where there is a slowdown in economic activity, monetary growth serves as economic stimulus that tends to improve stock markets. In this study, the elasticity coefficient of liquidity growth is 1.88 and statistically significant at $1 \%$ error level. Thus, one percentage increase in liquidity growth (broad money supply) has the potential to raise the GSE composite index by $1.88 \%$. Thus, the performance of Ghana's stock market is highly due to increased liquidity. The findings support Mukherjee and Naka (1995), Maysami and Koh (2000) and Ratanapakorn and Sharma (2007) inter alia who find a positive relationship between stock market performance and liquidity. Thus, people sometimes use stock markets to dispose excess liquidity since such assets are easily convertible into cash as compared to real assets. Perhaps, this is the reason for our results. If, however, individuals and investors, in general, decide to dispose excess liquidity via investing in real assets then obviously liquidity growth would be insignificant on stock markets. This could be the reason for the findings of Chancharat et al. (2007), Serletis (1993) and Pearce and Roley (1983).

In our quest to investigate the performance of Ghana's stock market, inflation was used to proxy macroeconomic instability. This is because macroeconomic instability increases volatility and uncertainty by eroding the value of currency. Rising levels of inflation has the potential of shifting resources from investment to consumption due to increased cost of living for individuals. Therefore, demand for market instruments tends to fall leading to a diminution in the volume of stock traded. In addition, the monetary policy responds to the increase in the rate of inflation with contractionary monetary policies, which has the potential to raise the discount rate thereby resulting in a reduction of present value of cash flows. In this case, a rise in inflation tends to impact negatively on stock market.

On the other hand, since inflation raises the general price levels it is possible to have stock prices and indices rising following a rise in inflation. In the present study, inflation deviates from the normal trend since its elasticity was positive and highly significant at $1 \%$ error level as found by Maysami et al. (2004), and Ratanapakorn and Sharma (2007). The implication is that if inflation rate should rise by one percent then GSE composite index would also rise by about $0.65 \%$. This revelation contravenes the conclusions of Chen et al. (1986), Mukherjee and Naka (1995), Wongbangpo and Sharma (2002) and Osei-Fosu and Osei-Fosu (2013) who reported a negative relationship between inflation and the stock market. This is because as inflation rises, price levels for all goods and services in the economy experience some form of upward adjustment. This is usually achieved via the high levels of sales revenue of most listed companies. On the other hand, equity investment serves a hedge against inflation and currency depreciation. Thus, most investors used the stock market to hedge against currency depreciation and price hikes in the country, hence the positive sign of inflation on GSE market within the period under study.

Finally, the study was interested in finding the impact of exchange rate on GSE performance due the rapid currency depreciation in recent years. Usually for import dependent economies, currency depreciation puts an unfavourable impact on a domestic stock market and Ghana is not an exception. Exchange rate elasticity was negative and significant at $1 \%$ error level. The implication is that increases in the price of foreign currencies leads to a depreciation of the local currency thereby causing a fall in stock market indices. This usually happens when people try to convert their cedi-denominated assets into foreign financial assets in a way to avoid losses from currency depreciation. From the above results, when dollar price rises by $1 \%$, stock market performance is expected to fall by about $0.22 \%$, a result similar to that of Osei-Fosu and Osei-Fosu (2013) under VAR/VECM methodology. Thus, currency depreciation jeopardises the fortunes of stock markets.

\section{Conclusion}

This study examined the inter-linkage between the GSE composite stock index and four macroeconomic variables with a focus on interest rate and liquidity growth within the framework of the robust estimation methodology. The findings in this study suggest that performance of Ghana Stock Exchange is mainly driven by liquidity growth, inflation in a positive manner and exchange rate in negative way. The study has revealed that interest rate effects on GSE index is insignificant though positive. Implications for policy makers is that prudent macroeconomic policies should be streamlined to stabilise the domestic currency, provide some level of economic stimulus in periods of low economic activity so as to ensure stability while maintaining some level of inflation to avoid slowdowns of the stock market.

\section{Acknowledgement}

The authors gratefully acknowledge the cooperation from the editorial office of this journal, and comments from the anonymous reviewers. All errors and misinterpretations, if any, are those of the authors

\section{Conflict of interest}

The authors declare to have no competing interest.

\section{References}

[1] Adjasi, C., Harvey, S. K., and Agyapong, D. (2008), Effect of Exchange Rate Volatility on the Ghana Stock Exchange, African Journal of Accounting, Economics, Finance and Banking Research, 3(3)

[2] Aduda, J., Masila, J. M., and Onsongo, E. N (2012), The Determinants of Stock Market Development: The Case for the Nairobi Stock Exchange, International Journal of Humanities and Social Science, 2(9).

[3] Anokye, M. A., and Tweneboah, G. (2008), Macroeconomic Factors and Stock Market Movement: Evidence from Ghana. MPRA Paper No.11256, Munich, Munich Personal RePEc Archives.

[4] Chancharat, S., Valadkhani, A., and Harvie, C. (2007), the Influence of International Stock Markets and Macroeconomic Variables on the Thai Stock Market. Faculty of Commerce - Papers (Archive), University of Wollongong.

[5] Chen, N. F., Roll, R. and Ross, S. A. (1986), Economic forces and the stock market, J. Bus., 59(3): 383-403. http://dx.doi.org/10.1086/296344.

[6] Engberg, H. L. (1975), Indigenization of the Business Sector through the Organized Capital Market: The Lagos Stock Exchange, Journal of Mgt Studies, 7(4).

[7] Gan, C., Lee, M., Yong, H. and Zhang, J. (2006), Macroeconomic variables and stock market interactions: New Zealand evidence. Int Mgt. Financ. Innov., 3(4): 89-101.

[8] Gujarati, D. N. (2004), Basic econometrics (4th ed.) Tata McGraw-Hill, New Delhi.

[9] Hamao, Y. (1988). An Empirical Investigation of the Arbitrage Pricing Theory. Japan and the World Economy, 1, 45-61. http://dx.doi.org/10.1016/0922-1425(88)90005-9.

[10] Huber, P. J. (1964) Robust Estimation of a Location Parameter, Annals of Mathematical Statistics 35:73-101. http://dx.doi.org/10.1214/aoms/1177703732.

[11] Khan, K. N. (2004) Inflation and Stock Market Performance: A Case Study for Pakistan, Savings and Development, 28(1): 87-101.

[12] Kuwornu, K. M., and Owusu-Nantwi, V (2011) Macroeconomic Variables and Stock Market Returns: Full Information Maximum 
Likelihood Estimation, Research Journal of Finance and Accounting, 2(4).

[13] Kyereboah-Coleman, A. and Agyire-Tettey, K. F. (2008) Impact of macroeconomic indicators on stock market performance: The case of the Ghana stock exchange. Journal of Risk Finance, 5(2).

[14] Maysami, R. C., and Koh, T. S. (2000) A Vector Error Correction Model of the Singapore Stock Market, International Review of Economics and Finance, 9:79-96. http://dx.doi.org/10.1016/S1059-0560(99)00042-8.

[15] Maysami, R. C., Howe, L. C. and Hamaz, M. A. (2004), Relationship between Macroeconomic Variables and Stock Market Indices: Cointegration Evidence from Stock Exchange of Singapore's All-S Sector Indices, Journal Penguruson, 24: 47-77.

[16] Mckinnon, R. (1973). Money and Capital in Economic Development. Washington D.C., Brookings Institution

[17] Mishkin, F. S. (2004) The Economics of Money, Banking and Financial Markets. $7^{\text {th }}$ Ed., 2004, Addison-Wesley Series in Economics, ISBN 0-321-12235-6.

[18] Mookerjee, R. and Yu, Q. (1997), Macroeconomic Variables and Stock Prices in small Open Economy: The case of Singapore, Pacific-Basin Finance Journal, 5: 377-788. http://dx.doi.org/10.1016/S0927-538X(96)00029-7.

[19] Mukherjee, T. K. and Naka, A. (1995), Dynamic relations between Macroeconomic Variables and the Japanese Stock Market: An application of a Vector Error Correction Model, The Journal of Financial Research, 2:223-237. http://dx.doi.org/10.1111/j.1475-6803.1995.tb00563.x.

[20] Mukhopadhyay, D. and Sakar, N. (2003), Stock returns and macroeconomic fundamentals in model specification framework: Evidence from Indian stock market. Discussion Paper, January, 1-28, Indian Statistical Institute, Economic Research Unit, ERU 2003-2005

[21] Ologunde, A. O., Elumilade, D. O. and Asaolu, T. O. (2006), Stock Market Capitalization and Interest Rate in Nigeria: A Time Series Analysis. International Research Journal of Finance and Economics, 4:154-166.

[22] Osamwonyi, I. O., and Evbayiro-Osagie, E. I. (2012), The Relationship between Macroeconomic Variables and Stock Market Index in Nigeria, Journal of Economics, 3(1):55-63.

[23] Osei, K.A. (2006), Macroeconomic factors and the Ghana stock market, African Finance Journal, 8:26-38.

[24] Osei-Fosu, A. K. and Osei-Fosu, A. K. (2013), Empirical investigation of the nexus between stock prices and exchange rates in Ghana, Ghanaian Journal of Economics, 1.

[25] Oyinlola, M. A., Adeniyi, O., and Omisakin, O. (2012), the Dynamics of Stock Prices and Exchange Rates: Evidence from Nigeria. Journal of Monetary and Economic Integration, 12(1).

[26] Pearce, D., and Roley, V. V. (1983), the Reaction of the Stock Prices to Unanticipated Changes in Money: a Note. The Journal of Finance, $38: 1323-1333$ http://dx.doi.org/10.1111/j.1540-6261.1983.tb02303.x.

[27] Ratanapakorn, O. and Sharma, S. C. (2007), Dynamics analysis between the US Stock Return and the Macroeconomics Variables, Applied Financial Economics, 17 (4): 369-377. http://dx.doi.org/10.1080/09603100600638944.

[28] Robert, D. G. (2008), Effect of macroeconomic variables on stock market returns for four emerging economies: Brazil, Russia, India and China. Int. Bus. Econ. Res. J., 7(3).

[29] Ross, S. A. (1976), the arbitrage theory of capital assets. J. Econ. $\begin{array}{lll}\text { Theory, } & \text { December, } & \text { 13(3): }\end{array}$ http://dx.doi.org/10.1016/0022-0531(76)90046-6.

[30] Rousseeuw, R. J., and Leroy, A. M. (1987), Robust Regression and Outlier Detection, New York: Wiley. http://dx.doi.org/10.1002/0471725382.

[31] Serletis, A. (1993), Money and Stock Prices in the United States, Applied Financial 3:51-54 http://dx.doi.org/10.1080/758527816.

[32] Shaw, E. (1973) Financial Deepening in Economic Development, New York, Oxford University Press.

[33] Singh, A. (1997) Financial Liberalization, Stock Markets and Economic Development, The Economic Journal, 107: 77-182 http://dx.doi.org/10.1111/j.1468-0297.1997.tb00042.x.

[34] Wongbangpo, P., and Sharma, S. C. (2002), Stock Market and Macroeconomic Fundamental Dynamic Interactions: ASEAN-5 Countries. Journal of Asian Economics, 13: 27-51: http://dx.doi.org/10.1016/S1049-0078(01)00111-7.

[35] Worthington, A. C., and Higgs, H. (2006), Evaluating Financial Development in Emerging Capital Markets with Efficiency Benchmarks, Faculty of Commerce Papers, University of Wollongong: available at : http://ro.uow.ed.au/commpapers/115. 